\title{
To What Extent Might Identity Theories Help Understand the Learning Process of EFL Students at Muhammadiyah University of Surakarta, Indonesia?
}

\author{
Susiati and Honest Ummi Kaltsum
}

\section{Introduction}

Corresponding Author:

Susiati

sus249@ums.ac.id

Received: 23 January 2019 Accepted: 26 February 2019 Published: 17 March 2019

Publishing services provided by Knowledge E

(c) Susiati and Honest Ummi Kaltsum. This article is distributed under the terms of the Commons Attribution License, which permits unrestricted use and redistribution provided that the original author and source are credited.

Selection and Peer-review under the responsibility of the International Seminar on Language, Education, and Culture Conference Committee.
Muhammadiyah University of Surakarta is an Islamic-based university located in Central Java province, Indonesia. The students mostly come from the same county, namely from Java. Having been teaching English for five years in the institution, I observe that some students avoided Debate. Inversely, other students did come to the classes and eagerly practiced debating. Based on these two distinctive attitudes among students on the subjects, a big question arises: why does the huge gap occur?

Before answering the question, I would like to describe what the Debate class first. The Debate class is a class participated by mostly Javanese students with various sects of Islam designed in the Department of English Education Curriculum as a compulsory module in year two, specifically in semester three. Every week, the students were given a topic to debate which was selected by me as a lecturer. However, this did not consistently happen. Sometimes, the students could choose the topics which favored them to debate. In this class, the students are expected to be able to use the appropriate expressions required discussion and debate, acquire skills in discussion and debate, express ideas smoothly, understand different rules in various debate system, and participate actively using different debating systems. Besides, a debating class is beneficial for students since it can improve students' critical thinking (Dewar, 2011). I agree with Dewar since 21 st century is an era when students develop strong critical thinking and interpersonal communication skills in order to be successful in an increasingly fluid, interconnected, and complex world (Bellisle, 2010). This is also my personal reason why I sometimes gave the students 'controversial topics' such as Feminism should be promoted for gender equality, Same-Sex Marriage should be legalized in Indonesia. In the end, they do not have to believe what are stated in the motions, but in order 
that they are aware of what are happening in the world and give their arguments. From the beginning, I have realized that the topics could make controversy. Besides, the Department curriculum obliges the students to come to the Debate class.

Based on this background and going back to the question, I believe that this gap is caused by students' different religious interpretations on Debate which the topics were about Feminism, LGBTQ (Lesbian, Gay, Bisexual, Trans, or Questioning), Deconstruction and Hermeneutics. It may be argued that many Moslems are ideologically inclined to be against such lessons if the lessons are correlated with Islam. In addition, their cultural background possibly affects how they see this class. One Javanese value (ewuhpekewuh - a Javanese value showing a guilty feeling if the deed is not satisfying others or an afraid feeling if disappointing others), which had existed before Islam came to Indonesia, may contribute to the presence of students in the classes. Javanese people, including Moslems, apply the value sometimes not because of religious teachings which also promote respect, tolerance, and peace, but because the value was brought by the ancient people and have been embedded in Javanese culture (Lisa, 2012). Perhaps, the curriculum obligation may drive the students willing to come to the class regardless they like the class or not. Therefore, this essay will elaborate on how the students' multiple identities, as Moslems and Javanese, as well as perhaps others, might play a role in their EFL learning process in Debate class.

Post-structuralist perspectives will play a role as the basis to see the multiple identities the students are currently attributed. Post-structuralists see identities as not stable and fixed, and that identity is not a self-concept which promotes self's typical distinguish from others. This perspective describes, one of them, students' interaction in the classroom (Watson-Gegeo, 2004).

This leads me to formulate the following essay question: to what extent might identity theories help understand the learning process of EFL students at Muhammadiyah University of Surakarta, Indonesia?

In the rest of this essay, I will divide the sections into three. Firstly, Literature Review will show the definitions of identity theories, Post-structuralist perspectives on identity, relevant empirical studies, Feminism and LGBTQ (Lesbian, Gay, Bisexual, Trans, or Questioning), religious background of students, cultural background of students, Islamic view on Feminism, Deconstruction and Hermeneutics, Islamic and Javanese views on Feminism, Deconstruction and Hermeneutics, willingness to communicate, unwillingness to communicate and non-participation, and characteristics of English as a Foreign Language learners. 
Secondly, Discussion of this essay will elaborate the following points: a) how some students' religious interpretation might affect the students' identity as language learners in the debating class, b) how Javanese value might affect the students' identity as language learners in the debating class, and c) can the two be brought together in some ways? D) other factors that might affect the students' identity in the debating class.

In the last part, there will be conclusion which will highlight the summary of the essay. Learning Implication and explicit answer of the essay question are also included.

\section{Literature Review}

\subsection{Identity theories}

The definitions of identity depend on the perspective they are seen from. There are at least three different views on identity: psychological, social and negotiated. On psychological perspective, identity is seen as a self-concept. How an individual is different from others. Therefore, vision and motivation play very important roles in preserving this identity, and this identity is considered stable and fixed (Dornyei, 2009).

The second viewpoint is that identity is perceived as socially constructed. An individual cannot claim that what makes them different from others is a core them, but an individual is the representative of a social group. Social identity theory originated from Tajfel and Turner (1979) on his work of social categorization. This view is often called a post-structuralist perspective as the identities are typically seen as fixed, stable and unchanging (Norton, 2000). However, Lave and Wenger (1991), still in social perspective, identity is seen as understanding learning. If a person joins a group, he/she will learn to adopt certain identity in the group. Hence, this view would argue that groups are indigenously built, shifting and changing, emerging and breaking up.

The third view of identity is the post-structuralist perspective. This is the opposite idea of that of the structuralist view as post-structuralists define identity as multi-faceted. A person has different group affiliations. Post-structuralists emphasize how a person interacts with the world. How a person interacts with other people from different selves and groups. They might presumably take up the identity from a group from where interaction occurs. That is why, identity is not stable and open to change (Lave \& Wenger, 1991).

In this essay, I use the definition of the post-structuralist perspective since every student works together in the classroom in the learning process. The identities currently attributed to them are multi-layered. They are Moslems, Javanese, and English as a Foreign Language learners. Post-structuralist perspective sees "all activities in which 
the learners regularly interact with others in the family, community, work place, or classroom are not only by definition socially organized and embedded in cultural meaning systems, but are inherently political. [...] There is no context-free language learning, and all communicative contexts involve social, cultural, and political dimensions that affect which linguistic forms are available or taught and how they are represented" (WatsonGegeo, 2004:340).

\subsection{Post-structuralist perspectives on identity}

Both Norton (2000) and Pavlenko and Blackledge (2003) argue Post- structuralist views on identity that refer to Bourdieu's (1977) ideas that linguistic practices are in the social arena, political, economic and cultural systems which in certain occasions have multi-meanings for different people. Pavlenko and Blackledge denote to Hellar's (1995) thought that particular ethnic identities are seen as problematic markers. "Ethnic identity is a dynamic, multidimensional construct that refers to one's identity, or sense of self as a member of an ethnic group" (Phinney, 2003:63). Trimble and Dickson (2005) added explanation on Phinney's definition that ethnic identity comprises culture, race, religion, language, kinship, or place of origin a subgroup shares with.

The students' cultural background, religion and place of origin at the Department of English Education at Muhammadiyah University of Surakarta, Indonesia might be the factors why some students avoided Debate and English Literature (especially on the topics of Feminism, Deconstructionism and Hermeneutics) classes, and other students are eager to join the classes.

Norton (2000) emphasizes post-structural identity more as the anti-theses of Saussure's (1966) structuralism to Bakhtin's (1981), Bourdeou's (1977), Fairclough's (1992), Gee's (1990), and Kress' (1989) theories of language. Norton explains that social meanings sometimes attributed to signs which have homogenous and consensual characteristics, cannot be explained in structuralism. Norton then concludes "the signifying practices of societies are sites of struggle, and that linguistic communities are heterogeneous arenas characterized by conflicting claims to truth and power (p.14). The students' identity as Moslems needs to be understood not as a homogenous group who have the same interpretation about the verses in the Qur'an and the way how they implement them in daily life. Yet, in this learning context the students' understanding of a verse in the Qur'an varies. Hence, Islam is a group of which the followers' interpretations even only on a verse of the Qur'an are not the same. These different sights may affect one's deeds 
are different from that of others. This may lead the conflict between what they believe and what is learnt in the classroom.

\subsection{Relevant studies}

Golombek and Jordan (2005) conducted research with two Taiwanese students in the first year of study in a second year of Master of Arts in TESOL (MATESOL) program. Using post-structuralist perspective on identity, they found that the two Taiwanese preservice teachers "have multiple and conflicting identities as legitimate speakers and teachers of English" (p.513). This research focused on how Master students who have become English pre-service teachers have conflicts with native speakerness. Meanwhile, this essay elaborates the conflicts between some students with some subjects taught in the classroom with cultural background plays important role.

Karmani (2005) studied TESOL after the 9/11 tragedy. He suggested that it was the role of western media which influence people to teach Arabian children more English and less Islam to cut the latent thought of terrorism. "Thus, in the light of the presentday global hostilities when we all seem to be alerted to be supposedly inevitable clash between Islam and the West, I wish here to outline, albeit very briefly, an urgent case for reconnecting the political and the spiritual with current TESOL practice in the ArabMuslim world (p.4). Karmani highlighted how the clash between Islam and the West is something unavoidable, and the clash deals with political and spiritual aspects. In my students' context, the conflict between Islam and the West would lie on some students' belief that Debate and certain English Literature topics' ways of thinking are not appropriate for Islam especially the messages in certain the Qu'ran's verses.

Relating to non-participation in identity case, Goldstein (1995) conducted an ethnographic study with female immigrants in Canada which are mostly from Portuguese. The female workers had problems with English where the people in the community speak .Although they struggled to achieve their English ability to speak with the people, they still could not understand what the people said. With desperate feeling, they eventually chose not to participate in the community. Which is not relevant of this study to my context is that the problems the immigrants encountered were they were not able to understand and express their ideas in English. However, the problems of the students in the Debate class are possibly their different interpretations on a Qur'an verse and Javanese values and the complexity of language use as in the Debate class, critical thinking is the key to successfully build good arguments. Therefore, the more complex the lessons are, the more sophisticated the language is used. 


\subsection{Feminism, deconstructionism, hermeneutics and LGBTQ}

\subsubsection{Feminism}

Feminism is a movement which has been popular for last century during the post-modern era which promotes the equality in social, political, and economic sectors to women (Hogan, 2014).

Halberstam (2012) describes Feminism as sexuality on women's body which is exposed for the sake of capital interest. His view is inspired by an American singer, Lady Gaga, who "become the vehicle for performing the very particular arrangements of bodies, genders, desires, communication, race, affect, and flow that we might now want to call gaga feminism" (p.xii).

Meanwhile, Taylor and Zine (2014) study the feminism of Moslem women to post-9/11 attack in the United States. They explain how Moslem after the attack are encouraged to "unveil" their bodies and life.

None of these two views represent the case of the students' reaction on Feminism. The students' emphasis is apparently more on the women liberation idea that women have equal or even higher position than men in public sectors.

\subsubsection{Deconstructionism}

Deconstructionism is Derrida's (1967) literary theory and philosophy of language. This theory is also one of post-modern studies. Deconstruction is a theory which re-questions a construct or permanent construct. Jenkins (1997) depicted the work of deconstruction as in the word history. This work was in Feminism perspective. He re- questioned why his-story not her-story?

What matters from deconstruction work to the students is if this method is used for deconstructing the meaning of verses in the Qur'an. While today, it appears to be more Moslems in the worldwide who use deconstruction method to interpret the Qur'an. The liberals would never mind with this idea. However, more conservative Moslems would reject this idea since it has its own method to interpret (Murad, 1997).

\subsubsection{Hermeneutics}

Hermeneutics is a practice of interpretation of a text which is originated by German scholar which was initially used to interpret the Bible (Porter \& Stovell, 2012). Within the 
development, Hermeneutics is now not only used to seek the meaning of the Bible, but also other texts such as historical scripture and even other holy books including the Qur'an (Mustafa, 2011).

Some students would mind with the explanation by the lecturer of allowing to interpret the Qur'an by Hermeneutics method.

\subsubsection{LGBTQ (Lesbian, Gay, Bisexual, Transgender, and Questioning)}

Sexual revolution has been spreading in the world since 1960 initiated by Western people including Italy and USA (Moore, 2015). However, although some Western countries have approved same-sex marriage as Holland and currently USA, for example, (ibid.), this is considered pro and con in many countries including Western countries. LGBTQ may not be popular in Eastern countries including Indonesia. The main controversy issue is on religious belief where every individual person in the country has religion, and none of the religions believe in same-sex marriage.

\subsection{Cultural background of students}

Accroding to Tomalin (2013), there are five aspects of cultures:

1. Cultural knowledge (what do you need to know about culture in order to make sense of cultural references in the language?

2. Cultural behavior (how people behave differently in the community whose language you are learning.

3. Cultural expectations (what do people in a culture expect of others' behavior?

4. Cultural style (what is my own cultural style and how does it differ from the target language community?

5. Cultural adaptation (how should I adapt to the target culture? This involves not just knowledge nut cultural skills.

The all points may be relevant to the contexts below especially point 1 and 2 . 


\subsection{Islamic view on debate}

One of the verses in the Qur'an, surah Al-Ankabut:46, mentions that it is forbidden to debate with the Ahlul Kitab (other religion adherents) to confront about otherreligion's holybooks.

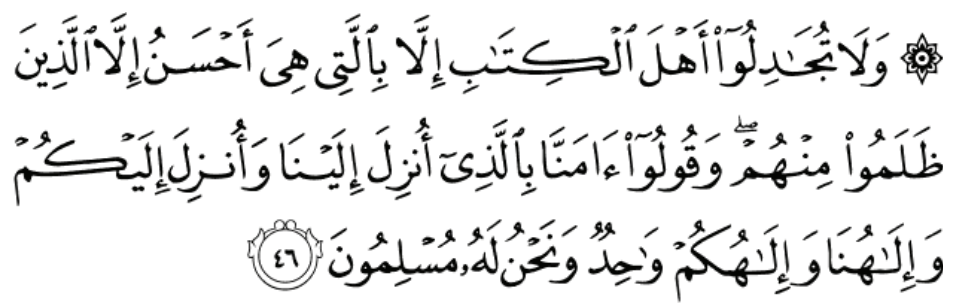

Which means: "And do not argue with the People of the Scripture except in a way that is best, except for those who commit injustice among them, and say, "We believe in that which has been revealed to us and revealed to you. And our God and your God is one; and we are Muslims [in submission] to Him." (http://quran.com/29/46).

This verse literally remarks that Muslims are forbidden to debate on Scripture inter religions. However, some Moslems generalize this as applicable to any topic. The students who avoided the Debate class seem to over generalize the meaning of the verse.

\subsection{Islamic and Javanese views on Feminism}

Islam and Javanese culture have similar points of view on women (Endraswara, 2010). Most Moslems would think that women are the sub-ordinate of men. Women should be obedient with their husband in everything. Husbands are seen as the decision makers in a family. This embedded view might be because of historical influence. In the past stories, women were presumably playing role to "serve" men such as sex servant during war period, slavery. Furthermore, surah An-Nisaa:10 says that the share of heritage for men is twice bigger that of women. Another verse, verse 3, still in the same surah, says that a husband is allowed to have until four wives. This might also affect Moslems' thought on women although in the same verse, it is also explained if the husband feels afraid not to be able to be just, they are just allowed to have one wife. The historical factor and the text of the Qur'an might affect most Moslems' way of thinking about women.

This thought seems rooted in most Moslems for hundred years although for last 50 years, as Feminism broadly have become a global topic to discuss, the number of career Moslem women has been increasing, and some Moslems, probably more, seem to realize that women's position only in domestic works are nurtured, not natural. Though, it 
is undeniable that currently most Moslem appear to still argue that men are upper than women.

In line with the Islamic perspective on Feminism, Javanese culture also places women as Konco Wingking (domestic works) or in the second class. Since the Java kingdom period, Javanese women have been assumed in the metaphor Masak (cooking meals in the kitchen), Macak (making- up face for their husband in front the mirror), and Manak (serving their husband on bed to make children) (Haryani, 2012).

Still, in this context, the students are Moslems and mostly Javanese who may have the same perspectives as mentioned above.

\subsection{Willingness, unwillingness to communicate and non-participation}

"Willingness to communicate (WTC) is a potentially fundamental for effective interaction and language production" (Alemi, et. Al, 2013:43). WTC is a concept based on verbal interactions among students. There are a number of studies about this in language classroom context. Alemi et. al., from their study of male and female's willingness to communicate comparison in the classroom, suggest that females are indicated to have more willingness to communicate. In addition, unlike males, females become less willing to communicate with age.

Furthermore, Willingness of Communicate are often correlated with Unwillingness to Communicate since if some students are active to speak, there must other students who are silent. Burgoon (1976) defined the unwillingness to communicate construct as a global communication construct representing the predisposition of "a chronic tendency to avoid and/or devalue oral communication" (p. 60). Burgoon (1976) considered two factors including approach-avoidance and reward, respectively, to determine how likely a person is to participate in communication and whether an individual finds communication rewarding or not.

In language classroom context, unwillingness to communicate may also relate to nonparticipation in the classroom. The non-participation of not being active to speak possibly because of the students' identity factor. The identity that they think they belong to can conflict with what they think something against their belonging (NCCA, 2012). This may affect to non-participation to speak in the classroom as what the students feel are between "love and hate" (Block, 2007:864) which Block calls this an Ambivalent. Such negation feelings are described by Bauman (1991) as "language specific disorder, the main symptom of ...[which] is the acute discomfort we feel when we are unable to read 
the situation properly and choose between alternative actions"(p.1). Therefore, avoidance to speak or even avoidance to come to classroom can be parts of the alternative actions.

\subsection{Characteristics of English as a foreign language (EFL) learners}

Nosratinia and Sarabchian (2013) divide big personality traits which can be seen in EFL learners into five categories as the following (p.90):

1. Extraversion: the extraversion dimension captures one's comfort level with relationships. While extraverts tend to be gregarious, assertive, and sociable, introverts tend to be reserved, timid, and quiet. Extraversion categorizes by positive effects and emotions and can be seen as a positive sensation, and introverts can be seen as the opposite.

2. Agreeableness: the agreeableness dimension refers to an individual's propensity to defer to others. Highly agreeable people are cooperative, warm, and trusting. People who score low on agreeableness are cold, disagreeable, and antagonistic.

3. Conscientiousness: the conscientiousness dimension is a measure of reliability. A highly conscientious person is responsible, organized, dependable, and persistent. Those who score low on this dimension are easily distracted, disorganized, and unreliable. In addition, conscientiousness dimension can be characterized by reliability, achievement-oriented, and orderly.

4. Emotional stability: the emotional stability dimension often labeled by its converse neuroticism-taps a person's ability to withstand stress. People with positive emotional stability tend to be calm, self-confident, and secure. Those with high negative scores tend to be nervous, anxious, depressed, and insecure.

5. Openness to experience: the openness to experience dimension addresses one's range of interests and fascination with novelty. Extremely open people are creative, curious, and artistically sensitive. Those at the other end of the openness category are conventional and find comfort in the familiar.

In their study, Nosratinia and Sarabchian categorize these learners' personalities to examine learners' critical thinking. To foster learners' critical thinking, they suggest that differences on learners 'personalities should be considered. These types of personalities could be used to indicate the students' personalities in the Debate class besides their religious and cultural background. 


\section{Discussion}

\subsection{How some students' religious interpretation might affect their identity as language learners in the Debate class}

There are different interpretations of the verse of Debate in surah Al-Ankabut:46. The interpretation of the verse depends on the students' background of Islamic sect (Karmani, 2005). Indeed, in the verse it is explicitly mentioned that what is forbidden is to debate verses of different holy books with other people with different religion. The Islamic sect in Indonesia varies principally consisting of three areas: conservative, moderate and liberal. He conservative one, like the Puritan in Christian described by Maitland (1957), typically reacts something with rebellion. The rebellion some students do seems by avoiding the Debate class. They may overgeneralize what they interpret about the verse is applicable for all activities including in the English debate in the Debate class.

The Debate class is actually aimed at building the students' critical thinking. The topics discussed are not about verses of holy books. Even, in the Debate rule, it is not allowed to be racial (Michael in Dewar 2011). The arguments built are not in an attempt to condemn other races such as ethnic, religion, color of skin. That is why, it might be a bit exaggeration if some students avoid the Debate class because the overgeneralization.

It is also a fact that few students appeared to avoid certain topics to debate. Practically in the classroom, a topic is given a week before the students practice to debate. The typical topics avoided are about Feminism and something taboo in the religion such as same-sex marriage. As far as I am concerned, some students seems not comfortable with the topics as seen as taboo, while other students eagerly practiced the topics. The latter type of students may be those who believe the verse on debate is not applicable for the debate practices in the classroom. Otherwise, their perspective on religion might be more neutral, or they come to Debate class to sharpen their ability of speaking no matter what topics are discussed. Therefore, as English learners, they should adapt the target culture and culture knowledge (Tomalin, 2013) as Feminism is a part of post-modern era (Hogan, 2014) in Western culture, English speaking countries.

Another lesson, Feminism, is popularly known as a sensitive topic in Islam. The AnNisaa's verses within the Javanese culture have long been embedded in many Moslems and Javanese people and apparently interpreted women in the second class after men. Feminism is the anti-thesis of their interpretation on women. The equality to men and liberation of women seems to be thought as movement which hinder and omit the "religious values". 
Deconstruction and Hermeneutics are two sciences of interpretation many Moslems against with if they are used to interpret the Qur'an. Meanwhile, some Moslems who might be less conservative would not mind with the ideas of seeking meaning of the Qur'an's verses with Deconstruction and Hemeneutics.

The controversy in the English Literature class at the university lies on the lecturer's statement that those two methods are applicable for the Qur'an by giving examples of the interpretation using the two methods. The students' reactions would be diverse. Some disagree by personally complaining to the Head of Department. Others would think those sciences are two new ways to interpret texts and may not take seriously about the application of the two methods for the Qur'an interpretation.

\subsection{How Javanese values might affect their identity as language learners in the Debate class}

The most outstanding Javanese cultures which might contribute to some students' view are ewuh-pekewuh and viewpoint on women as konco wingking (Endraswara, 2010). As mentioned in the literature review, the guilty feeling if not satisfying others or ewuhpekewuh could be the factor of some students to attend to the Debate and certain English Literature classes although they might not agree with the ways of thinking of the subject and materials.

General perspective on women in Java that places women as konco wingking (a friend in behind) who do domestic works (cook, make-up and make sex service) might affect some students to be inclined to against Feminism ideas. Debate, Deconstruction and Hermeneutics seem not "opposing" lessons to Javanese culture.

However as time passes and the assimilation of presumably western culture, the value reduces and there are more Javanese women who go to public sector, for example the Princess of Surakarta who ran to Regional House of Representative election in 2009 which never happened before (ibid). It is in line with post-structural perspective that identity is not stable and open to change (ibid.).

\subsection{Can the two be brought together in some ways?}

From the discussion the previous two points, a question arises: can Islam and Javanese culture can be brought together in some ways for the students' case?

Based on the literature review the discussions, I would say it is Feminism which doubly bring controversy in language learning at the university. Islam and Javanese culture 
are together contrast with Feminism ideas, although I believe Javanese sentiment of Feminism is not negative compared to that of Islam (Haryani, 2012).

\subsection{Other factors that might affect the students' identity as language learners in the Debate class}

Since Debate is a matter of criticality in thinking (Dewar, 2011), the used may be more complex. The vocabulary and structure could demand higher level of language. Therefore, speaking English in the Debate class may be difficult in the Debate class. Furthermore, as EFL students, where English is not used in their daily life, expressing high content could be difficult. However, there were some students who eagerly came and showed good performance. This can be indicated by the personalities proposed by Nosratinia and Sarabchian (2013) that he students who did not want to speak may have low score in extraversion as they could be less gregarious, agreeableness as they might be less cooperative because in debate, the students must work with their team, and they could also have low score in conscientiousness as debate needs persistence to make good performance (Dewar, 2011). Therefore, the students' identity as language learners could be affected by their personality traits.

Another factor of their avoidance to the Debate class could be their unwillingness to communicate. In a classroom, there must be some students who are silent while the others active to speak (Burgoon, 1976). This unwillingness to communicate in the debate class can be indicated that in one side they like attending English speaking class because they are English language students and probably expect to work with English after graduate. On the other side, they may not like the 'difficult topics', not like to think hard to build an argument, and not have adequate English fluency to speak or shyness. This is what is so called ambivalence by Block (2007). Therefore, the ambivalence feeling could affect their identity as language learners in the Debate class.

Finally, curriculum obligatory can be one factor why the students came to the classroom. This case is same as that of the female immigrants in Canada (Goldstein, 1995) that the immigrants probably must go to the community since they were working there, but they did not speak in English with the others. The students must go to the classroom because the class is a part of the Department curriculum, but they did not want to practice to speak possibly because of the factors mentioned in the previous paragraphs. Hence, their non-participation because of feeling obliged with the institution system may affect their presence to the Debate class. 
From the four points of discussion, I would add that students behavior toward learning might change over time. For the case of religious interpretation, I would reflect to my own experience that I was a student with the conservative type. I did not think that Debate was a good activity since it seemed not to be appropriate with religion's lessons. Time to time, my knowledge has improved until I was aware that Debate is good and most strategic way to build critical thinking. My interpretation of the Debate verse in the Qur'an changed when I researched and discussed it more with others.

This vignette can be a reflection for Debate and particular English Literature lecturers to give steady understanding to the students that opening mind is important to gain new knowledge and the students do not have to apply the methods which are seen not appropriate with the religion's teachings in their real life, but it not impossible for students try new things.

\section{Conclusion}

The conclusions drawn are as the following:

1. Post-structural perspective on identity helps understand the case of the students at the Department of English Education, Muhammadiyah University of Surakarta, Indonesia in a classroom activity and have conflicting claims of truth (Norton, 2000) which can be changed over time.

2. That the interpretation of verse in the Qur'an on Debate shows a discrepancy among students. The interpretation may change over time with more knowledge and experience gained.

3. Javanese cultures may contribute to the attitudes of students toward learning especially on Feminism, not really in Deconstruction and Hermenetics.

4. There is a meeting point between Islam and Javanese culture to see Feminism, although Islam is stricter in this case.

5. Complex language use and unwillingness to communicate be other factors why some students did not want to practice to speak English in the English Debate class

6. Curriculum compulsory could be also one pragmatic factor why the students came to the English Debate class.

The implication could be the teachers' awareness to understand the students' different personalities. For the curriculum designer, English Debate class may be better put 
in the higher level of students, not in the second year who are mostly in intermediate fluency level.

This paper gives information to English teachers which may encounter the similar case to be more aware. This essay is open to research more but seen from structuralist perspective. How the students as Moslems and Javanese interact to non-Moslems and non-Javanese with the same subjects to view.

\section{References}

[1] Bellisle, P. (n.d.) 21st Century Skills. Available from: http://www.sophia.org/tutorials/ 21st-century-skills [Accessed March 25th, 2015]

[2] Block, D. (2007) The Rise of Identity in SLA Research, Post Firth and Wagner (1997), The Modern Language Journal 91, 863-876.

[3] Bourdieu, P. (1977) Outline of a Theory of Practice. New York: Cambridge University Press.

[4] Dewar, G. (2011) Debate Lessons Improve Critical Thinking Skills. Available from: http://www.parentingscience.com/debate-improves-critical-thinking-skills.html [Accessed March 19th, 2015]

[5] Dornyei, Z. (2009) Motivation, Language Identity and L2 Self (Second Language Acquisition). Great Britain: MPG Books Ltd.

[6] Endraswara. (2010) Falsafah Jawa. Yogyakarta: Cakrawala. Fairclough, N. (1992). Critical Language Awareness. USA: Longman.

[7] Golombek, P. and Stefanie, R.J. (2005) Becoming "Black Lambs" not “Parrots": A PostStructuralist Orietation to Intelliginility and Identity, TESOL quarterly, 39(3), 513-533.

[8] Halberstam, J.J. (2012) Gaga Feminism. England: Pearson.

[9] Hellar, M. (1995) Language Choice, Social Institution and Symbolic Domination, Language and Society, 24, 373-405.

[10] Jenkins, K. (1997). Postmodern History Readers. London: Routledge.

[11] Lave, J. and Wenger, E. (1991) Situated learning: Legitimate peripheral participation. Cambridge: Cambridge University Press.

[12] McCroskey, J. C. (1984). The communication apprehension perspectice. In J. A Daly \& J. C. McCroskey (Eds.), Avoiding communication: Shyness, reticence, and communication apprehension (pp. 13-38). Beverly Hills, CA: Sage.

[13] Norton, B. (2000). Identity and Language Learning: Gender, Ethnicity and Educational Change. Edinburgh: Pearson Education Limited. 
[14] Nosratinia, M. and Sarabchian, E. (2013) The Role of Personality Traits in Predicting EFL Learners' Critical Thinking Skills: A Study on Psychological Characteristics of EFL Learners, losjournal of Humanism (18), 89-93

[15] Pavlenko and Blackledge. (2003). Negotiation of Identities in Multilingual Contexts. England: Routledge.

[16] Phinney, J. S. (2003). Ethnic identity and acculturation. In K. M. Chun, P. B. Organista \& G. Marín (Eds.), Acculturation: Advances in Theory, Measurement, and Applied Research.(pp. 63-81). Washington: APA.

[17] Porter, S.E. and Stovell, M. (2012). Bible Hermeneutics. USA: Green Press Initiative.

[18] Schmid, C.L. (2001). The Politics of Language: Conflict, Identity, and Cultural Pluralism in Comparative Perspective. Oxford: Oxford University Press.

[19] Tajfel, H., \& Turner, J. C. (1979). An integrative theory of intergroup conflict. The social psychology of intergroup relations?, 33, 47.

[20] Taylor and Zine (2014). Muslim Women, Transnational Feminism and the Ethics of Pedagogy: Contested Imaginaries in post-9/11 cultural practice. New York: Routledge.

[21] The Nobel Qur'an (n.d) Available from: http://quran.com/29/46 [Accessed March 19th, 2015].

[22] Trimble, J.E. and Dickson, R. (2005) Ethnic Identity. Thousand Oaks: Sage.

[23] Watson-Gegeo, K. A. (2004). Mind, Language, and Epistemology: Toward a Language Socialization PFaradigm for SLA. The Modern Language Journal, 88(3), 331-350. 